\title{
REVISED
}

\section{Functionalization of an Iridium-Diamidocarbene Complex by Ligand-Based Reactions with Titanocene and Zirconocene Sources}

Allegra L. Liberman-Martin, Micah S. Ziegler, Antonio G. DiPasquale, Robert G. Bergman, T. Don Tilley

Department of Chemistry, University of California, Berkeley, Berkeley, California 94720, United States

Dedication: This paper is dedicated to Professor Malcolm L. H. Green, a long-time friend and a pioneer in the exploratory chemistry of metallocenes and other organometallic compounds.

\begin{abstract}
A ( $\left.{ }^{(} \mathrm{Bu}-\mathrm{DAC}\right) \operatorname{Ir}(\mathrm{COD}) \mathrm{Cl}$ complex ( ${ }^{\mathrm{B}} \mathrm{Bu}-\mathrm{DAC}=1,3$-bis(N-tert-butyl)diamidocarbene, $\mathrm{COD}=1,5$-cyclooctadiene) reacts with titanocene(II) and zirconocene(II) sources to form heterobimetallic complexes by metallocene coordination at the remote oxalamide binding site. Structural and spectroscopic data reveal the formation of a doubly-reduced [ $\left.{ }^{t} \mathrm{Bu}-\mathrm{DAC}\right]^{2-}$ ligand upon metallocene complexation. The metallocene-substituted complexes catalyze benzaldehyde hydrosilation at rates over an order of magnitude faster than those observed with the parent iridium complex.
\end{abstract}

\section{Introduction}

The rate and selectivity of organometallic reactions can be dramatically influenced by the electronic environment of the metal center. Traditionally, to gain mechanistic insight on ligand effects for a metal-mediated reaction, a series of independently-synthesized ligands and their corresponding metal complexes must be prepared. An alternative strategy uses a remote ligand functionalization to "switch" the electronic properties of a complex [1]. This late-stage modification allows for the rapid synthesis of a series of complexes from a common precursor, and reactivity differences between these complexes provide insight into the electronic preferences for a reaction.

$\mathrm{N}$-heterocyclic carbenes (NHCs) are versatile ligands for a wide range of metal-catalyzed transformations [2]. While variation of NHC steric properties can be readily achieved, it remains difficult to significantly alter their electronic properties [3]. The late-stage functionalization of NHC ligands is of interest as a strategy for the convenient synthesis of NHCs with diverse electronic properties. Recent reports have utilized chemical [4], electrochemical [5], or photochemical [6] stimuli to tune NHC donor properties; however, studies comparing the reactivity of these switchable complexes remain rare.

Herein, we report electronic modification of an iridium-diamidocarbene complex by ligand-based reactions with titanocene(II) and zirconocene(II) sources. Upon metallocene binding, three resonance contributors can be envisioned depending on the extent to which the metallocene reduces the diamidocarbene ligand (A-C, Figure 1) [7]. A combination of X-ray crystallographic, UV-vis and NMR spectroscopic data suggests that the diamidocarbene ligand is doubly reduced upon interaction with the $\mathrm{Cp}_{2} \mathrm{Ti}$ or $\mathrm{Cp}_{2} \mathrm{Zr}$ fragments, and this ligand reduction renders the carbene donor more electron rich. Iridium-catalyzed hydrosilation is accelerated by 


\section{REVISED}

over an order of magnitude for the metallocene-substituted complexes, demonstrating that ligand-based modification alters electronic properties, and therefore catalytic activity, of these complexes.

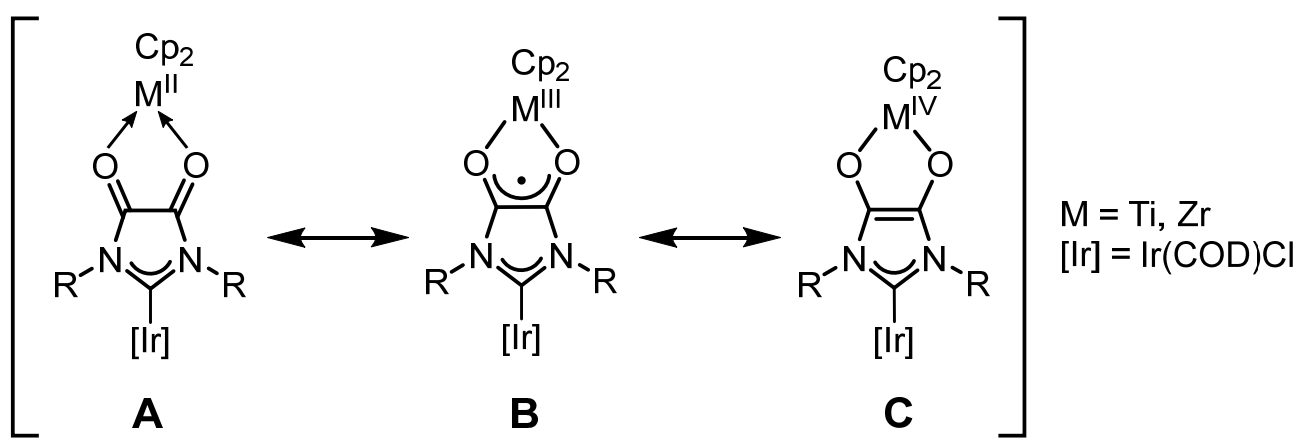

Figure 1. Three possible resonance contributors for the metallocene-diamidocarbene platform.

\section{Results and Discussion}

The recently reported 1,3-bis(N-tert-butyl)diamidocarbene ('Bu-DAC) [8] ligand platform was selected for remote functionalization studies due to the presence of both a carbene donor and a secondary $\alpha$-dicarbonyl functional group. Treatment of $[\operatorname{Ir}(\mathrm{COD}) \mathrm{Cl}]_{2}$ with 2 equivalents of ${ }^{t} \mathrm{Bu}-\mathrm{DAC}$ in toluene generated $\left({ }^{t} \mathrm{Bu}-\mathrm{DAC}\right) \operatorname{Ir}(\mathrm{COD}) \mathrm{Cl}(\mathbf{1})$, which was isolated as a yellow-green powder in $83 \%$ yield. The blue titanocene adduct ( $\left.\mathrm{Cp}_{2} \mathrm{Ti}-{ }^{\mathrm{t}} \mathrm{Bu}-\mathrm{DAC}\right) \mathrm{Ir}(\mathrm{COD}) \mathrm{Cl}$ (2) was generated by treatment of 1 with bis(cyclopentadienyl)titanium-bis(trimethylsilyl)acetylene [9] in THF, and was isolated in $90 \%$ yield (eq 1). Lastly, the orange zirconocene derivative $\left(\mathrm{Cp} 2 \mathrm{Zr}-{ }^{t} \mathrm{Bu}-\mathrm{DAC}\right) \operatorname{Ir}(\mathrm{COD}) \mathrm{Cl} \quad(\mathbf{3}$, eq 2) was prepared by addition of bis(cyclopentadienyl)zirconium dicarbonyl [10] to 1 in toluene (95\% isolated yield).

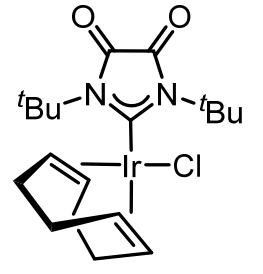

1

1

1

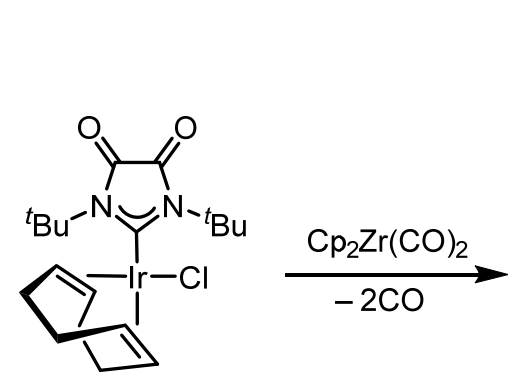

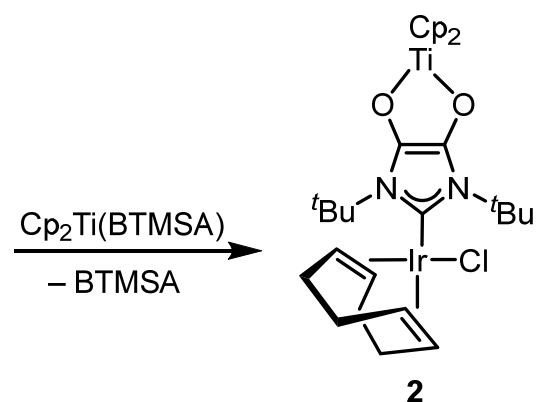<smiles></smiles>

3 


\section{REVISED}

X-ray crystallographic characterization of 1-3 allowed for solid-state structural comparisons (Figures 2-4). All three complexes feature the expected square-planar geometry of $\mathrm{a} \mathrm{d}^{8}$ iridium complex. Complexes 2 and $\mathbf{3}$ contain the $\mathrm{Cp}_{2} \mathrm{M}(\mathrm{M}=\mathrm{Ti}, \mathrm{Zr})$ fragment bound to the $\alpha$-dicarbonyl site of the ${ }^{t} \mathrm{Bu}$-DAC ligand.

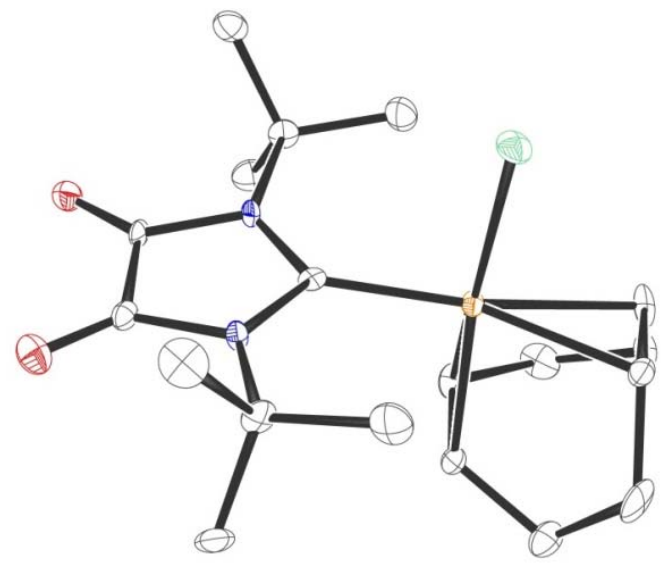

Figure 2. ORTEP diagram of 1, with hydrogen atoms omitted for clarity and thermal ellipsoids shown at $50 \%$.

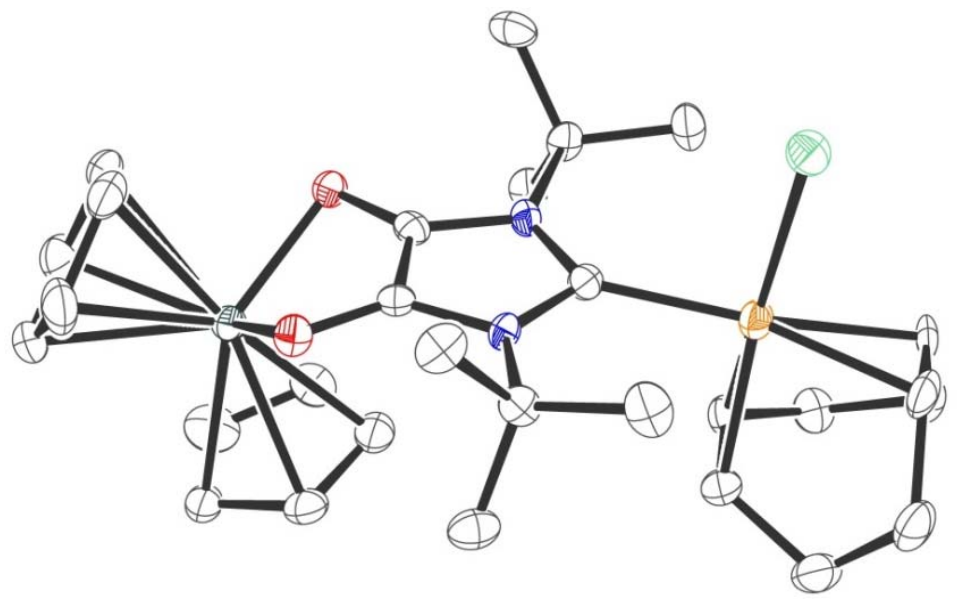

Figure 3. ORTEP diagram of 2, with hydrogen atoms omitted for clarity and thermal ellipsoids shown at $50 \%$. 


\section{REVISED}

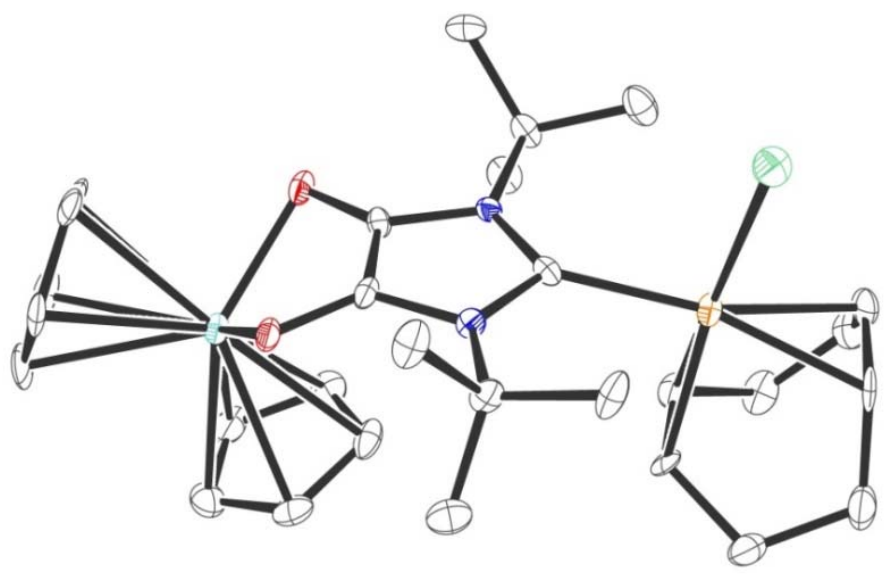

Figure 4. ORTEP diagram of $\mathbf{3}$, with hydrogen atoms omitted for clarity and thermal ellipsoids shown at $50 \%$.

A comparison of selected bond lengths of 1-3 (Figure 5) indicates that metallocene coordination causes elongation of the $\mathrm{C}_{\text {amide }}-\mathrm{O}$ bond length of the ${ }^{t} \mathrm{Bu}-\mathrm{DAC}$ ligand $\left(\mathrm{C}_{\text {amide }}-\mathrm{O}\right.$ (avg) of 1.198(11) $\AA$ for 1, 1.313(3) $\AA$ for 2 , and 1.331(3) $\AA$ for 3). In contrast, the $\mathrm{C}_{\text {amide }}-\mathrm{C}_{\text {amide }}$ bond length is substantially contracted upon metallocene binding (1.505(19), 1.373(5), and 1.377(5) $\AA$ for $\mathbf{1}, \mathbf{2}$, and $\mathbf{3}$, respectively). The bond distances of $\mathbf{2}$ and $\mathbf{3}$ are consistent with a dominant contribution from a [ $\left.{ }^{t} \mathrm{Bu}-\mathrm{DAC}\right]^{2-}$ ene-diolate resonance form $(\mathbf{C}$, Figure 1) [11]. The Ir- $\mathrm{C}_{\text {carbene }}$ bond length of $\mathbf{1}$ is quite short (1.964(13) $\AA$ ), which can be attributed to strong $\pi$ backbonding from iridium to the diamidocarbene ligand [12]. The $\mathrm{Ir}-\mathrm{C}_{\text {carbene }}$ distance is increased for derivatives 2 and 3 (2.056(4) and 2.068(3) $\AA$, respectively), suggesting that the $\pi$ acceptor properties of ${ }^{t} \mathrm{Bu}-\mathrm{DAC}$ are diminished upon derivatization with the $\mathrm{Cp}_{2} \mathrm{Ti}$ and $\mathrm{Cp}_{2} \mathrm{Zr}$ fragments.

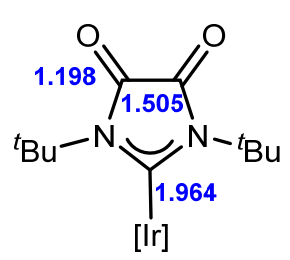

1

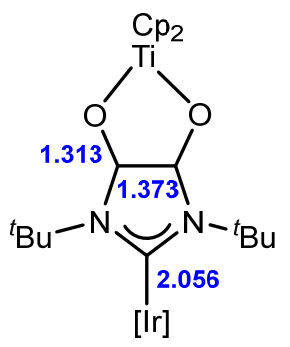

2

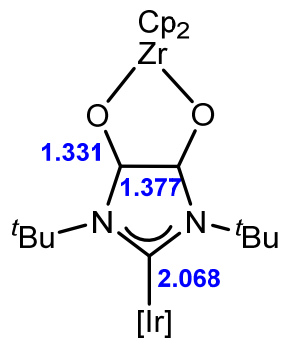

3

Figure 5. Selected bond distances (in $\AA$ ) for complexes 1-3. $\mathrm{C}_{\text {amide }}-\mathrm{O}$ bond lengths are average values.

UV-vis spectra of 1-3 in THF are presented in Figure 6. Intense low-energy transitions are observed for 2 and 3 at $580 \mathrm{~nm}\left(\varepsilon_{\max }=15,100 \mathrm{M}^{-1} \mathrm{~cm}^{-1}\right)$ and $415 \mathrm{~nm}\left(\varepsilon_{\max }=14,200 \mathrm{M}^{-1} \mathrm{~cm}^{-}\right.$ ${ }^{1}$ ), respectively. The intensity of these absorptions is consistent with their assignment as ligandto-metal charge-transfer (LMCT) transitions from the electron rich [ $\mathrm{Bu}-\mathrm{DAC}]^{2-}$ ligand to the $\mathrm{d}^{0}$ titanium and zirconium centers of $\mathbf{2}$ and $\mathbf{3}$ [13]. This LMCT transition occurs at a longer wavelength for $\mathbf{2}$ than for $\mathbf{3}$ due to the greater electrophilicity of titanium relative to zirconium [14]. 


\section{REVISED}

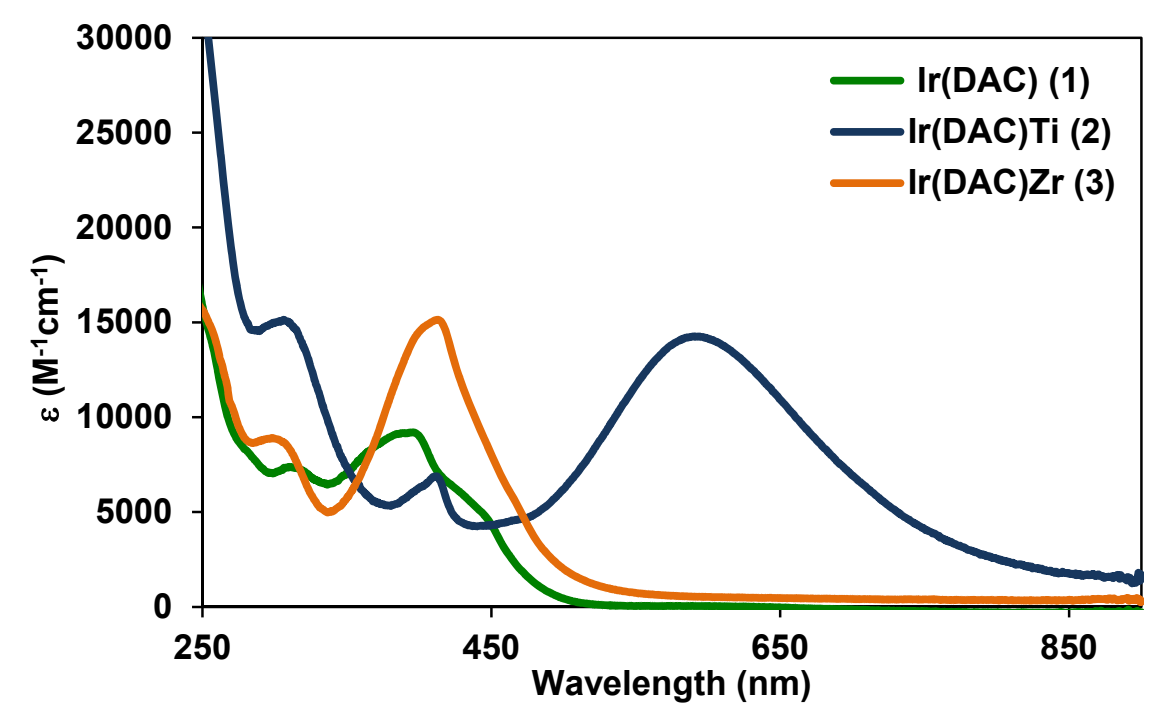

Figure 6. Absorption spectra of complexes 1-3 in THF.

Complexes 1-3 are diamagnetic, consistent with the proposed major resonance contributor $\mathbf{C}$ (Figure 1). The ${ }^{13} \mathrm{C}$ NMR resonance corresponding to the $\mathrm{C}_{\text {amide }}$ position of $\mathbf{1}$ is observed at $156.2 \mathrm{ppm}$, while the analogous signals for $\mathbf{2}$ and $\mathbf{3}$ are observed at 129.4 and 125.4 ppm, respectively. The chemical shifts for $\mathbf{2}$ and $\mathbf{3}$ are consistent with previously reported enediolate complexes (128-133 ppm) [15]. A low-field carbene resonance for 1 was observed at $237.5 \mathrm{ppm}$ in the ${ }^{13} \mathrm{C}\left\{{ }^{1} \mathrm{H}\right\}$ NMR spectrum. The downfield ${ }^{13} \mathrm{C}$ chemical shifts observed for other metal-diamidocarbene complexes have been attributed to the electrophilic character of these ligands [12]. In contrast, the carbenic resonances for $\mathbf{2}$ and $\mathbf{3}$ are observed at 192.0 and 183.3 ppm, respectively, similar to those of other five-membered NHC complexes in the literature (typical range between 179 and 208 ppm) [16].

The ${ }^{1} \mathrm{H}$ chemical shift of the COD ligand trans to the carbene is diagnostic of the electronic changes transmitted to the iridium center [17]. Upon metallocene complexation, there is an upfield shift of this ${ }^{1} \mathrm{H}$ NMR resonance $(\delta=5.0 \mathrm{ppm}$ for $1,4.5 \mathrm{ppm}$ for 2 , and $4.4 \mathrm{ppm}$ for $3)$. These chemical shift changes suggest that $\pi$-backbonding to COD is increased upon addition of titanocene or zirconocene, consistent with metallocene incorporation generating a more electron-rich iridium center. Unfortunately, attempts to prepare the corresponding ( ${ }^{t} \mathrm{Bu}-$ $\mathrm{DAC}) \operatorname{Ir}(\mathrm{CO})_{2} \mathrm{Cl}$ complexes to allow for comparison of IR stretching frequencies were unsuccessful.

Hydrosilation of aldehydes was selected to assess the catalytic reactivity of 1-3 [18]. Benzaldehyde hydrosilation with 3.0 equiv of diphenylsilane and $3 \mathrm{~mol} \%$ of catalysts $\mathbf{1 - 3}$ proceeded at $70{ }^{\circ} \mathrm{C}$ to selectively form the corresponding silyl ether product in high yield (eq 3 , 94\% yield, determined by ${ }^{1} \mathrm{H}$ NMR spectroscopy). Catalyst activity was substantially improved by remote binding of $\mathrm{Cp}_{2} \mathrm{Ti}$ and $\mathrm{Cp}_{2} \mathrm{Zr}$ fragments, as determined by ${ }^{1} \mathrm{H}$ NMR spectroscopic monitoring of product formation $\left(t_{1 / 2}=300 \mathrm{~min}\right.$ for $\mathbf{1}, 8 \mathrm{~min}$ for $\mathbf{2}$, and $15 \mathrm{~min}$ for $\left.\mathbf{3}\right)$. These results suggest that while the electronic properties of $\mathbf{2}$ and $\mathbf{3}$ differ significantly from $\mathbf{1}$, there are minimal differences between the electron contributions of the $\mathrm{Cp}_{2} \mathrm{Ti}$ and $\mathrm{Cp}_{2} \mathrm{Zr}$ substituents. 


\section{REVISED}

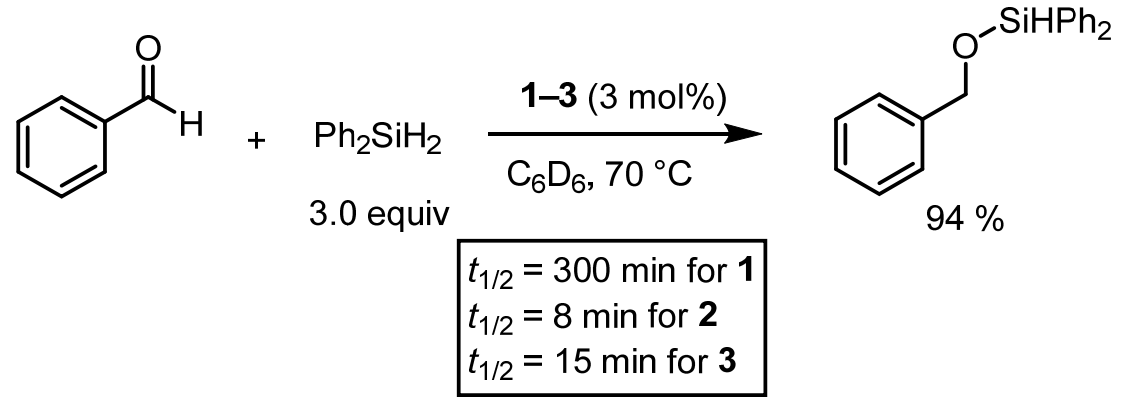

\section{Conclusion}

In summary, we have reported a convenient method for the late-stage functionalization of an iridium-bound diamidocarbene ligand by reactions with titanocene and zirconocene sources. These functionalizations convert the diamidocarbene ligand from an $\alpha$-dicarbonyl oxidation level to the ene-diolate form upon metallocene binding, resulting in a more electron rich carbene donor. Preliminary studies of aldehyde hydrosilation catalysis demonstrate that the heterobimetallic $\left(\mathrm{Cp}_{2} \mathrm{M}-{ }^{\mathrm{t}} \mathrm{Bu}-\mathrm{DAC}\right)-\mathrm{Ir}(\mathrm{COD}) \mathrm{Cl}$ complexes $(\mathrm{M}=\mathrm{Ti}, \mathrm{Zr})$ have improved activity relative to the iridium precursor. We hope that future studies will apply this electronic tuning strategy to a variety of catalytic transformations.

\section{Experimental}

\subsection{General Considerations}

All experiments were conducted using standard Schlenk techniques or in a nitrogen atmosphere glovebox. Solvents were stored over $3 \AA$ molecular sieves after drying with a JC Meyers Phoenix SDS solvent purification system. Deuterated solvents were purchased from Cambridge Isotope Laboratories and were degassed and dried using appropriate drying agents prior to use. Starting materials, including the (1,5-cyclooctadiene)iridium(I) chloride dimer [19], 1,3-bis(N-tert-butyl)diamidocarbene [8], bis(cyclopentadienyl)titaniumbis(trimethylsilyl)acetylene [9], and bis(cyclopentadienyl)zirconium dicarbonyl [10] were prepared using literature procedures.

Solution NMR spectroscopy was performed using Bruker NMR spectrometers at $20^{\circ} \mathrm{C}$, unless otherwise noted. ${ }^{1} \mathrm{H}$ and ${ }^{13} \mathrm{C}$ NMR spectra were calibrated internally to the residual proteo solvent relative to tetramethylsilane [20]. UV-vis spectra were collected on a Shimadzu UV$2450 \mathrm{UV}$-Visible spectrophotometer using UVProbe software (v. 2.21). Elemental analyses were performed by the University of California, Berkeley College of Chemistry Microanalytical Facility. For elemental analysis results of samples containing solvent molecules, the percentage of solvent was confirmed by ${ }^{1} \mathrm{H}$ NMR spectroscopy.

Single crystal X-ray diffraction was performed at the UC Berkeley CheXray crystallographic facility. Measurements were performed on a Bruker AXS diffractometer with a goniostat coupled to an APEX-II CCD area detector with Mo K $\alpha$ radiation $(\lambda=0.71073 \AA)$ monochromated by QUAZAR multilayer mirrors. Crystals were maintained at 100(2) K during collection. Data collection, refinement, and reduction were performed with Bruker APEX2 software (v. 2013.4 or 2014.1). Structures were solved with DIRDIF-2008 or SHELXT-2014 software and refined with SHELXL-2014 software with refinement of $F^{2}$ against all reflections 


\section{REVISED}

by full-matrix least squares. Unless otherwise noted, non-hydrogen atoms were refined anisotropically, and hydrogen atoms were included at geometrically-calculated positions and refined using a riding model.

\subsection{Synthesis of ( ${ }^{(B u-D A C)} \operatorname{Ir}(C O D) C l(\mathbf{1})$.}

A solution of 1,3-bis( $N$-tert-butyl)diamidocarbene $(45.4 \mathrm{mg}, 0.216 \mathrm{mmol})$ in $5 \mathrm{~mL}$ of toluene was added dropwise to a stirred solution of (1,5-cyclooctadiene)iridium(I)chloride dimer $(72.4 \mathrm{mg}, 0.108 \mathrm{mmol})$ in toluene $(5 \mathrm{~mL})$. A color change of the solution from red to yellowgreen occurred within 30 minutes. After 3 hours, volatile components were removed under reduced pressure, and the resulting solid was washed with pentane $(2 \times 3 \mathrm{~mL})$. Recrystallization from a toluene/pentane mixture $(1: 3)$ at $-30{ }^{\circ} \mathrm{C}$ allowed isolation of $\left({ }^{t} \mathrm{Bu}-\mathrm{DAC}\right) \operatorname{Ir}(\mathrm{COD}) \mathrm{Cl}(\mathbf{1})$ as a green crystalline solid $(97.0 \mathrm{mg}, 83 \%) .{ }^{1} \mathrm{H}$ NMR (THF- $\left.d_{8}, 600 \mathrm{MHz}\right) \delta 5.04(\mathrm{~m}, 2 \mathrm{H}), 2.92(\mathrm{~m}$, $2 \mathrm{H}), 2.37(\mathrm{~m}, 4 \mathrm{H}), 2.02(\mathrm{~s}, 18 \mathrm{H}), 1.95(\mathrm{~m}, 2 \mathrm{H}), 1.78(\mathrm{~m}, 2 \mathrm{H}) ;{ }^{13} \mathrm{C}\left\{{ }^{1} \mathrm{H}\right\}$ NMR (THF-d8, 150.9 $\mathrm{MHz}) \delta 237.46,156.17,92.52,62.66,56.41,33.63,31.80,29.05$. Anal. Calc. for $\mathrm{C}_{19} \mathrm{H}_{30} \mathrm{ClIIN}_{2} \mathrm{O}_{2} \cdot 0.2 \mathrm{C}_{7} \mathrm{H}_{8}(\%) \mathrm{C} 43.40, \mathrm{H}$ 5.64, N 4.96; found $\mathrm{C} 43.16, \mathrm{H} 5.52, \mathrm{~N} 5.08$.

\subsection{Synthesis of (Cp2Ti- $\left.{ }^{t} \mathrm{Bu}-\mathrm{DAC}\right) \operatorname{Ir}(\mathrm{COD}) \mathrm{Cl}$ (2).}

A solution of bis(cyclopentadienyl)titanium-bis(trimethylsilyl)acetylene (10.4 mg, $0.0293 \mathrm{mmol})$ in THF $(5 \mathrm{~mL})$ was added dropwise to a solution of $1(15.8 \mathrm{mg}, 0.0293 \mathrm{mmol})$ in THF $(3 \mathrm{~mL})$, resulting in an immediate color change of the solution from yellow-green to dark blue. After 30 minutes, volatile components were removed under reduced pressure, and trituration with pentane $(3 \times 2 \mathrm{~mL})$ allowed isolation of pure $\left(\mathrm{Cp}_{2} \mathrm{Ti}^{\mathrm{t}}{ }^{\mathrm{Bu}} \mathrm{Bu}-\mathrm{DAC}\right) \operatorname{Ir}(\mathrm{COD}) \mathrm{Cl}(2)$ as a blue powder $(19.1 \mathrm{mg}, 90 \%)$. Crystals of 2 suitable for X-ray diffraction were grown by layering a solution of 2 in fluorobenzene with pentane at $-30{ }^{\circ} \mathrm{C}$. ${ }^{1} \mathrm{H}$ NMR (THF- $\left.d 8,600 \mathrm{MHz}\right) \delta$ $6.01(\mathrm{~s}, 5 \mathrm{H}), 5.46(\mathrm{~s}, 5 \mathrm{H}), 4.51(\mathrm{~m}, 2 \mathrm{H}), 2.57(\mathrm{~m}, 2 \mathrm{H}), 2.22(\mathrm{~m}, 4 \mathrm{H}), 2.03(\mathrm{~s}, 18 \mathrm{H}) 1.57(\mathrm{~m}, 2 \mathrm{H})$, $1.38(\mathrm{~m}, 2 \mathrm{H}) ;{ }^{13} \mathrm{C}\left\{{ }^{1} \mathrm{H}\right\}$ NMR (THF-d8, $\left.150.9 \mathrm{MHz}\right) \delta 192.04,129.38,115.06,109.71,79.92$, 61.08, 51.24, 33.84, 32.80, 30.02. Anal. Calc. for $\mathrm{C}_{2} \mathrm{H}_{40} \mathrm{ClIrN}_{2} \mathrm{O}_{2} \mathrm{Ti}(\%) \mathrm{C} 48.10, \mathrm{H} \mathrm{5.57,} \mathrm{N}$ 3.87; found C 47.97, H 5.51, N 3.73.

\subsection{Synthesis of (Cp2Zr- $\left.{ }^{t} \mathrm{Bu}-\mathrm{DAC}\right) \operatorname{Ir}(\mathrm{COD}) \mathrm{Cl}(3)$.}

To a solution of $1(15.0 \mathrm{mg}, 0.0276 \mathrm{mmol})$ in toluene $(3 \mathrm{~mL})$ was added a solution of bis(cyclopentadienyl)zirconium dicarbonyl $(7.5 \mathrm{mg}, 0.0276 \mathrm{mmol})$ in toluene $(4 \mathrm{~mL})$. After 2 hours, volatile components were removed in vacuo to afford $\left(\mathrm{Cp}_{2} \mathrm{Zr}-{ }^{t} \mathrm{Bu}-\mathrm{DAC}\right) \operatorname{Ir}(\mathrm{COD}) \mathrm{Cl}(\mathbf{3})$ as an orange powder $(21.3 \mathrm{mg}, 95 \%)$. Single crystals of $\mathbf{3}$ were grown by vapor diffusion of diethyl ether into a THF solution of 3 at $-30{ }^{\circ} \mathrm{C} .{ }^{1} \mathrm{H}$ NMR (THF- $\left.d_{8}, 600 \mathrm{MHz}\right) \delta 6.28(\mathrm{~s}, 5 \mathrm{H}), 5.73(\mathrm{~s}$, $5 \mathrm{H}), 4.43(\mathrm{~m}, 2 \mathrm{H}), 2.58(\mathrm{~m}, 2 \mathrm{H}), 2.20(\mathrm{~m}, 4 \mathrm{H}), 2.04(\mathrm{~s}, 18 \mathrm{H}), 1.49(\mathrm{~m}, 2 \mathrm{H}), 1.32(\mathrm{~m}, 2 \mathrm{H})$; ${ }^{13} \mathrm{C}\left\{{ }^{1} \mathrm{H}\right\}$ NMR (THF-d8, $\left.150.9 \mathrm{MHz}\right) \delta 183.27,125.44,114.79,111.08,78.55,61.17,50.62$, 34.01, 33.16, 30.18. Anal. Calc. for $\mathrm{C}_{2}{ }_{2} \mathrm{H}_{40} \mathrm{ClIrN}_{2} \mathrm{O}_{2} \mathrm{Zr}$ (\%) C 45.38, H 5.25, N 3.65; found C 45.75; H 5.39, N 3.65. 


\section{REVISED}

\subsection{Hydrosilation catalysis}

A solution of iridium complex 1, $\mathbf{2}$, or $\mathbf{3}(1.1 \mu \mathrm{mol})$, diphenylsilane $(21 \mu \mathrm{L}, 0.11 \mathrm{mmol})$, benzaldehyde $(4.2 \mu \mathrm{L}, 0.037 \mathrm{mmol})$, and tetrakis(trimethylsilyl)silane as an internal standard, was prepared in $0.500 \mathrm{~mL}$ of benzene- $d_{6}$ in a J. Young NMR tube. The tube was placed in an NMR spectrometer with the temperature pre-equilibrated to $70{ }^{\circ} \mathrm{C}$, and the formation of diphenylbenzyloxysilane [21] was monitored by ${ }^{1} \mathrm{H}$ NMR spectroscopy.

\section{Acknowledgements}

This work was supported by the Director, Office of Science, Office of Basic Energy Sciences of the US Department of Energy under contract no. DE-AC02-05CH11231. We also acknowledge the National Institutes of Health for funding of the CheXray X-ray crystallographic facility (College of Chemistry, University of California, Berkeley) under grant number S10RR027172 and the Berkeley College of Chemistry NMR facility under grant SRR023679A.

\section{References}

[1] (a) U. Lüning, Angew. Chem., Int. Ed. 51 (2012) 8163.

(b) F. Cisnetti, C. Gibard, A. Gautier, J. Organomet. Chem. 782 (2015) 22.

(c) I.M. Lorkovic, R.R. Duff, M.S. Wrighton, J. Am. Chem. Soc. 117 (1995) 3617.

(d) A.M. Allgeier, C.A. Mirkin, Angew. Chem., Int. Ed. 37 (1998) 894.

(e) B.Y. Lee, G.C. Bazan, J. Vela, Z.J.A. Komon, X. Bu, J. Am. Chem. Soc. 123 (2001) 5352.

(f) Y.H. Kim, T.H. Kim, B.Y. Lee, D. Woodmansee, X. Bu, G.C. Bazan, Organometallics 21 (2002) 3082.

(g) A.L. Liberman-Martin, R.G. Bergman, T.D. Tilley, J. Am. Chem. Soc. 135 (2013) 9612.

(h) C. Brennan, A. Draksharapu, W.R. Browne, J.J. McGarvey, J.G. Vos, M.T. Pryce, Dalton Trans. 42 (2013) 2546.

(i) K.-N.T. Tseng, J.W. Kampf, N.K. Szymczak, ACS Catal. 5 (2015) 411.

(j) M.R. Kita, A.J.M. Miller, J. Am. Chem. Soc. 136 (2014) 14519.

(k) J.B. Geri, N.K. Szymczak, J. Am. Chem. Soc. 137 (2015) 12808.

(1) K.T. Horak, D.G. VanderVelde, T. Agapie, Organometallics 34 (2015) 4753.

(m) A.L. Liberman-Martin, D.S. Levine, W. Liu, R.G. Bergman, T.D. Tilley, Organometallics, 2016, DOI: 10.1021/acs.organomet.5b01003.

[2] (a) W.A. Herrmann, Angew. Chem., Int. Ed. 41 (2002) 1290.

(b) E. Peris, R.H. Crabtree, Coord. Chem. Rev. 248 (2004) 2239.

(c) S. Diez-Gonzalez, N. Marion, S.P. Nolan, Chem. Rev. 109 (2009) 3612.

(d) G.C. Vougioukalakis, R.H. Grubbs, Chem. Rev. 110 (2010) 1746.

[3] S. Würtz, F. Glorius, Acc. Chem. Res. 41 (2008) 1523.

[4] (a) A.T. Biju, K. Hirano, R. Fröhlich, F. Glorius, Chem. Asian J. 4 (2009) 1786.

(b) N. Vujkovic, V. César, N. Lugan, G. Lavigne, Chem. Eur. J. 17 (2011) 13151. 


\section{REVISED}

(c) B. Hildebrandt, W. Frank, C. Ganter, Organometallics 30 (2011) 3483.

(d) H. Valdés, M. Poyatos, E. Peris, Organometallics 33 (2014) 394.

[5] (a) E.L. Rosen, C.D. Varnado Jr., A.G. Tennyson, D.M. Khramov, J.W. Kamplain, D.H. Sung, P.T. Cresswell, V.M. Lynch, C.W. Bielawski, Organometallics 28 (2009) 6695.

(b) L. Hettmanczyk, S. Manck, C. Hoyer, S. Hohloch, B. Sarkar, Chem. Commun. 51 (2015) 10949.

[6] (a) V.W.-W. Yam, J.K.-W. Lee, C.-C. Ko, N. Zhu, J. Am. Chem. Soc. 131 (2009) 912.

(b) B.M. Neilson, V. M. Lynch, C.W. Bielawski, Angew. Chem., Int. Ed. 50 (2011) 10322.

[7] D.L.J. Broere, R. Plessius, J.I. van der Vlugt, Chem. Soc. Rev. 44 (2015) 6886.

(c) B.M. Neilson, C.W. Bielawski, Organometallics 32 (2013) 3121.

[8] J.P. Moerdyk, C.W. Bielawski, Chem. Commun. 50 (2014) 4551.

[9] P. Binger, P. Müller, F. Langhauser, F. Sandmeyer, P. Philipps, B. Gabor, R. Mynott, Chem. Ber. 126 (1993) 1541.

[10] D.J. Sikora, K.J. Moriarty, M.D. Rausch, A.R. Bulls, J.E. Bercaw, V.D. Patel, A.J. Carty, in: J.M. Shreeve (Ed.) Inorg. Synth., Volume 24, John Wiley \& Sons, Inc., Hoboken, NJ, USA, 1986, p. 147.

[11] (a) G. Fachinetti, C. Floriani, H. Stoeckli-Evans, J. Chem. Soc., Dalton Trans. 23 (1977) 2297.

(b) L.-C. Song, P.-C. Liu, C. Han, Q.-M. Hu, J. Organomet. Chem. 648 (2002) 119.

(c) J. Conradie, Int. J. Quant. Chem. 110 (2010) 1100.

(d) P. Zanello, M. Corsini, Coord. Chem. Rev. 250 (2006) 2000.

[12] (a) T.W. Hudnall, C.W. Bielawski, J. Am. Chem. Soc. 131 (2009) 16039.

(b) V. César, N. Lugan, G. Lavigne, Eur. J. Inorg. Chem. 2010, 361.

(c) M. Braun, W. Frank, G.J. Reiss, C. Ganter, Organometallics 29 (2010) 4418.

(d) M. Braun, W. Frank, C. Ganter, Organometallics 31 (2012) 1927.

(e) G.A. Blake, J.P. Moerdyk, C.W. Bielawski, Organometallics 31 (2012) 3373.

(f) L.R. Collins, J.P. Lowe, M.F. Mahon, R.C. Poulten, M.K. Whittlesey, Inorg. Chem.

53 (2014) 2699.

(g) L.R. Collins, I.M. Riddlestone, M.F. Mahon, M.K. Whittlesey, Chem. Eur. J. 21 (2015) 14075.

[13] (a) G. Erker, R. Noe, J. Chem. Soc., Dalton Trans. 1991, 685.

(b) P. Hofmann, M. Frede, P. Stauffert, W. Lasser, U. Thewalt, Angew. Chem., Int. Ed. Engl. 24 (1985) 712.

[14] G. Szigethy, A.F. Heyduk, Inorg. Chem. 50 (2011) 125.

[15] (a) J.M. Manriquez, D.R. McAlister, R.D. Sanner, J.E. Bercaw, J. Am. Chem. Soc. 100 (1978) 2716.

(b) G.M. Ferrence, R. McDonald, J. Takats, Angew. Chem., Int. Ed. 38 (1999) 2233.

(c) C.C. Cummins, G.D. Van Duyne, C.P. Schaller, P.T. Wolczanski, Organometallics 10 (1991) 164.

(d) M.D. Anker, M.S. Hill, J.P. Lowe, M.F. Mahon, Angew. Chem., Int. Ed. 54 (2015) 10009.

[16] R.A. Kelly III, H. Clavier, S. Giudice, N.M. Scott, E.D. Stevens, J. Bordner, I. Samardjiev, C.D. Hoff, L. Cavallo, S.P. Nolan, Organometallics 27 (2008) 202.

[17] J.W. Ogle, S.A. Miller, Chem. Commun. 2009, 5728. 


\section{REVISED}

[18] Examples of ketone and aldehyde hydrosilation by rhodium and iridium complexes supported by NHCs:

(a) M.F. Lappert, R.K. Maskell, J. Organomet. Chem. 264 (1984) 217.

(b) W.A. Herrmann, L.J. Goossen, C. Köcher, G.R.J. Artus, Angew. Chem., Int. Ed. 35 (1996) 2805.

(c) A.R. Chianese, R.H. Crabtree, Organometallics 24 (2005) 4432.

(d) H. Sato, T. Fujihara, Y. Obora, M. Tokunaga, J. Kiyosu, Y. Tsuji, Chem. Commun. 2007, 269.

(e) M. Nonnenmacher, D. Kunz, F. Rominger, Organometallics 27 (2008) 1561.

(f) I. Özdemir, S. Demir, O. Şahin, O. Büyükgüngör, B. Çetinkaya, Appl. Organomet. Chem. 22 (2008) 59.

(g) A.R. Chianese, A. Mo, D. Datta, Organometallics 28 (2009) 465.

[19] J.L. Herde, J.C. Lambert, C.V. Senoff, M.A. Cushing, in: G.W. Parshall (Ed.) Inorg. Synth., Volume 15, John Wiley \& Sons, Inc., Hoboken, NJ, USA, 1974, p. 18.

[20] G.R. Fulmer, A.J.M. Miller, N.H. Sherden, H.E. Gottlieb, A. Nudelman, B.M. Stoltz, J.E. Bercaw, K.I. Goldberg, Organometallics 29 (2010) 2176.

[21] J. Yang, T.D. Tilley, Angew. Chem., Int. Ed. 49 (2010) 10186. 


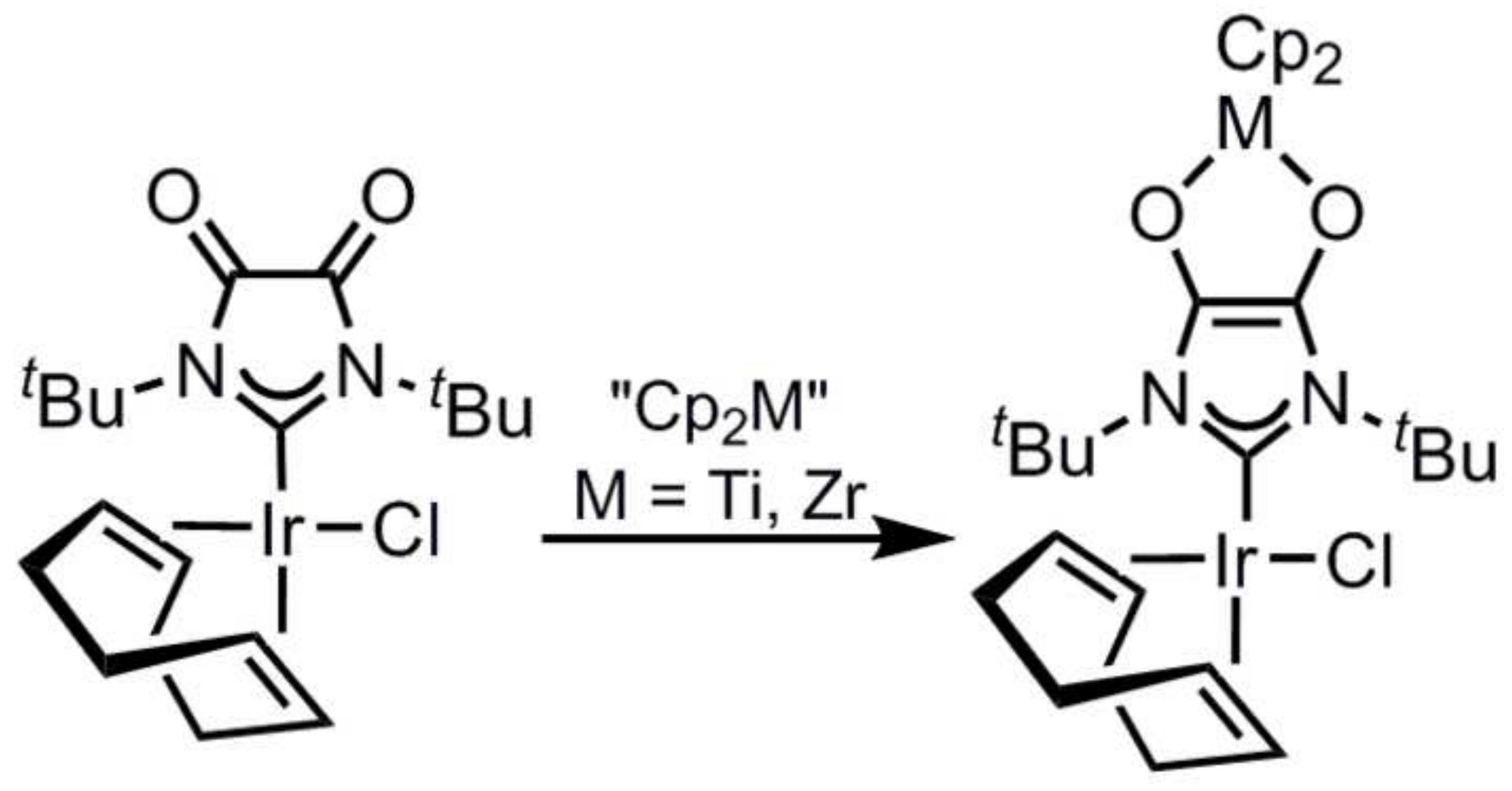

